\title{
Targeting Resident Memory T Cells for Cancer Immunotherapy
}

\author{
Charlotte Blanc', Sophie Hans', Thi Tran', Clemence Granier', Antonin Saldman', \\ Marie Anson ${ }^{1}$, Stephane Oudard ${ }^{1,2}$ and Eric Tartour ${ }^{1,3 *}$
}

${ }^{1}$ INSERM U970, Paris Cardiovascular Research Center (PARCC), Université Paris Descartes, Paris, France, ${ }^{2}$ Hôpital Européen Georges Pompidou, Department of Medical Oncology, Assistance Publique des Hôpitaux de Paris, Paris, France, ${ }^{3}$ Hôpital Européen Georges Pompidou, Laboratory of Immunology, Assistance Publique des Hôpitaux de Paris, Paris, France

\section{OPEN ACCESS}

Edited by:

Jeffrey C. Nolz,

Oregon Health \& Science

University, United States

Reviewed by:

Walter J. Storkus,

University of Pittsburgh,

United States

Karl Kai McKinstry,

University of Central Florida,

United States

*Correspondence:

Eric Tartour

eric.tartour@aphp.fr

Specialty section:

This article was submitted to Immunological Memory, a section of the journal

Frontiers in Immunology

Received: 17 May 2018 Accepted: 12 July 2018

Published: 27 July 2018

Citation:

Blanc C, Hans S, Tran T, Granier C, Saldman A, Anson M, Oudard S and Tartour E (2018) Targeting

Resident Memory T Cells for Cancer Immunotherapy.

Front. Immunol. 9:1722.

doi: 10.3389/fimmu.2018.01722
A novel population of memory $\mathrm{CD}^{+} \mathrm{T}$ cells called resident memory $T$ cells $\left(\mathrm{T}_{\mathrm{RM}}\right)$ has been identified based on their phenotype (CD103, CD69) and on their local tissue residency without recirculating in the blood. These cells have been implicated in protective immune response against pathogens in both animal models and humans. Their role in cancer is just emerging as a key player in tumor immunosurveillance. Many properties of these cells suggest that they could control tumor growth: (i) they respond much faster to reexposure to cognate antigen than circulating memory cells, (ii) they express high levels of cytotoxic molecules, and (iii) they are enriched in tumor-specific T cells in close contact with tumor cells. $\mathrm{T}_{\mathrm{RM}}$ are present in many human cancers and are associated with a good clinical outcome independently of the infiltration of $\mathrm{CD}^{+} \mathrm{T}$ cells. It has been recently shown that the efficacy of cancer vaccines depends on their ability to elicit $T_{\mathrm{RM}}$. In adoptive cell therapy, the transfer of cells with the ability to establish $\mathrm{T}_{\mathrm{RM}}$ at the tumor site correlates with the potency of this approach. Interestingly, $T_{R M}$ express immune checkpoint molecules and preliminary data showed that they could expand early during anti-PD-1 treatment, and thus be considered as a surrogate marker of response to immunotherapy. Some cues to better expand these cells in vivo and improve the success of cancer immunotherapy include using mucosal routes of immunization, targeting subpopulations of dendritic cells as well as local signal at the mucosal site to recruit them in mucosal tissue.

\section{Keywords: resident memory T cells, cancer vaccine, immune checkpoint molecule, mucosal route of vaccination, immunotherapy}

\section{INTRODUCTION}

After studying herpes simplex virus infection and lymphocytic choriomeningitis virus infection, two groups reported that memory $\mathrm{T}$ cells remain in dorsal root ganglia and small intestines, respectively, without recirculating through the blood $(1,2)$. These cells were called tissue-resident memory $\mathrm{T}$ cells $\left(T_{R M}\right)$. These $T_{R M}$ cells may persist for a long time and represent one of the main lymphocyte populations in adults $(3,4)$.

$\mathrm{T}_{\mathrm{RM}}$ cells originate from a common $\mathrm{KLRG}^{\text {neg }}$ memory precursor cell that also gives rise to circulating central and effector memory CD8 T cell populations (5). These cells share TCR repertoires (6).

$\mathrm{T}_{\mathrm{RM}}$ cells from different tissues were transcriptionally related (5) with a core marker (CD69, CD103, and CD49a) both in mice and humans. However, subpopulations of $\mathrm{T}_{\mathrm{RM}}$ differing by the expression of these markers and exhibiting additional markers also exist. For example, CD49a is expressed by 
only $15 \%$ of T cells from the human skin. The chemokine receptor CCR8 and the CD $8 \alpha \alpha$ homodimer are expressed only in skin $\mathrm{T}_{\mathrm{RM}}$ cells, while the aryl hydrocarbon receptor (AHR) is expressed in gut and skin $\mathrm{T}_{\mathrm{RM}}$, but not in lung $\mathrm{T}_{\mathrm{RM}}(5,7)$. This phenotypic heterogeneity extends to functional heterogeneity even within a same organ. For example, it has been shown that the airway $\mathrm{T}_{\mathrm{RM}}$ has a poor in vivo proliferative and cytolytic ability, when they were compared with lung $\mathrm{T}_{\mathrm{RM}}$, while IFN $\gamma$ are produced faster by $\mathrm{CD} 8 \mathrm{~T}_{\mathrm{RM}}$ compared to systemic effector $\mathrm{CD} 8^{+} \mathrm{T}$ cells (8). In addition, $\mathrm{T}_{\mathrm{RM}}$ in the airway has a short half-life (less than 1 month) whereas $\mathrm{T}_{\mathrm{RM}}$ in lung parenchyma may persist for several months or years (9).

$\mathrm{T}_{\mathrm{RM}}$ cells express high levels of protein associated with tissue retention, such as RGS-1 and RGS-2, both known as G protein-coupled inhibitors. By contrast, they display low levels of sphingosine-1-phosphate receptor 1 (S1PR1) and CCR7 (5, 10), which are indispensable for tissue exit. Various molecules expressed by $\mathrm{T}_{\mathrm{RM}}$ may explain their long survival in tissue. Indeed, anti-apoptotic factors such as Bcl-2 could be detected in $\mathrm{T}_{\mathrm{RM}}$ (5). In the presence of exogenous free fatty acids (FFAs), $\mathrm{CD}^{+} \mathrm{T}_{\mathrm{RM}}$ cells exhibited high levels of mitochondrial oxidative metabolism. This feature was not observed in central memory CD8 ${ }^{+}$T cells. Fabp 4 and Fabp5 (Fabp4/Fabp5) proteins favor FFA uptake by $\mathrm{CD}^{+} \mathrm{T}_{\mathrm{RM}}$ cells. Their specific deficiency on $\mathrm{T}$ cells decreased the survival of $\mathrm{T}_{\mathrm{RM}}$ in vivo (11).

Downregulation of T-bet, likely induced by TGF- $\beta$ and T-box proteins Eomesodermin, is required for $\mathrm{T}_{\mathrm{RM}}$ differentiation, but residual levels of T-bet for maintaining IL-15R are crucial for long-term $\mathrm{T}_{\mathrm{RM}}$ function and survival in the skin, kidney, and salivary gland (12). However, IL-15 is not required for their maintenance in the small intestine or female reproductive tract (FRT) (5).

Aryl hydrocarbon receptor and Notch activity are also required for the maintenance of $\mathrm{CD}_{103}{ }^{+} \mathrm{T}_{\mathrm{RM}}$ cells $(13,14)$. Recent studies by Milner et al. identified the transcription factor Runx3 as a master regulator for inducing and maintaining $\mathrm{CD}^{+} \mathrm{T}_{\mathrm{RM}}$ by reducing $\mathrm{T}_{\mathrm{RM}}$ apoptosis (15).

In addition, in some tissue localizations (e.g., brain or lung), the presence of antigen is required for $\mathrm{T}_{\mathrm{RM}}$ establishment $(16,17)$. By contrast, local inflammatory signal without antigenic stimulation may favor systemic $\mathrm{CD}^{+} \mathrm{T}$ cells to adopt $\mathrm{T}_{\mathrm{RM}}$-like characteristics in skin, nasal tissue, and FRT (18).

$\mathrm{T}_{\mathrm{RM}}$ have all the features of memory $\mathrm{CD} 8^{+} \mathrm{T}$ cells $\left(\mathrm{CD} 45 \mathrm{RA}^{-}\right.$ $\left.\mathrm{CD}^{2} \mathrm{~L}^{-} \mathrm{CD} 28^{-} \mathrm{CD}^{-} 7^{-} \mathrm{CCR}^{-}\right)(19,20)$. It has been clearly established that, at least in some tissues, $\mathrm{T}_{\mathrm{RM}}$ cells might persist without the secondary recruitment of systemic effector memory T cells (21).

\section{PROPERTIES OF $T_{\text {RM }}$ THAT MAY EXPLAIN THEIR ROLE IN A TUMOR CONTEXT}

Various studies have shown that $\mathrm{T}_{\mathrm{RM}}$ cells respond much faster to reexposure to cognate antigen than circulating memory cells [either TEM (effector memory T cells) or TCM (central memory $\mathrm{T}$ cells)] $(22,23)$. In addition, $\mathrm{T}_{\mathrm{RM}}$ underwent in situ division after local antigen challenge, triggered the recruitment of innate immune cells and recirculating memory $\mathrm{T}$ cells and thus regulated local immunosurveillance (22-24).

$\mathrm{T}_{\mathrm{RM}}$ cells in non-small cell lung cancer (NSCLC) are preloaded with preformed mRNA encoding inflammatory cytokines (granzyme B, IFN- $\gamma$, and TNF) and with cytotoxic molecules (13). In ovarian cancer, $\mathrm{CD}_{103^{+}}$tumor-infiltrating lymphocytes (TILs) uniformly express TIA-1, a marker of potential cytotoxicity (25). In liver cancer, $\mathrm{T}_{\mathrm{RM}}$ express high levels of perforin (26). CD49a expression has been demonstrated to characterize $\mathrm{T}_{\mathrm{RM}}$ cells poised with cytotoxic function in the human epidermis (27).

In some tissues such as the brain or the lung, local antigen presentation is required to drive $\mathrm{T}_{\mathrm{RM}}$ cell formation (17). In addition, CD103+ TILs express high levels of PD-1 (25), which has been reported to be a marker of antitumor TILs in melanoma (28). Indeed, after their sorting based on their expression of PD-1, $\mathrm{CD}^{+} \mathrm{T}$ cells that expressed this inhibitory receptor in melanoma patients identified those that preferentially recognized tumor cells $(28,29)$. From these results, it thus appears that in many localizations, $\mathrm{T}_{\mathrm{RM}}$ may represent antitumor-specific $\mathrm{T}$ cells.

In healthy tissues such as the lungs, the skin, the reproductive tract, and the gut, $\mathrm{T}_{\mathrm{RM}}$ cells localize within the epithelial layer. $\mathrm{CD} 03^{+}$TILs were preferentially localized in epithelial regions of tumors in close contact with tumor cells, likely due to the natural interaction between CD103, and its ligand, E-cadherin, expressed by tumor cells, may explain that CD $103^{+}$TIL were rather found in close contact with the tumor cells rather than in the stroma $(25,30)$.

Finally, it has been shown that $\mathrm{T}_{\mathrm{RM}}$ represent an effective in situ first line of defense to tissue-specific infections and are implicated in protective immune responses against many pathogens in both animal models and humans. It is thus tempting to extrapolate their role from infectious models to cancer (31).

\section{$T_{\text {RM IN THE NATURAL COURSE OF }}$ TUMOR}

$\mathrm{T}_{\mathrm{RM}}$ are present in many human cancers (NSCLC, ovarian cancer, bladder cancer, endometrial cancer, melanoma, etc.).

Overall, they are associated with a good clinical outcome $(19,32)$. Interestingly, the impact of $\mathrm{T}_{\mathrm{RM}}$ on survival was independent of the infiltration of $\mathrm{CD}^{+} \mathrm{T}$ cells. Indeed, we have shown in a multivariate analysis (33) that intratumoral $\mathrm{CD} 103^{+} \mathrm{CD}^{+} \mathrm{T}$ cells correlate with a better survival in NSCLC patient (33). Confirming our results, a greater number of intratumoral $\mathrm{T}_{\mathrm{RM}}$ cells correlated with a better survival in lung cancer, cervical cancer, and melanoma, independently of that conferred by total CD ${ }^{+} \mathrm{T}$ cells (34-36).

Finally, intratumoral $\mathrm{CD}^{+} \mathrm{T}$ cells not expressing CD103 were associated with poor prognosis, as observed in tumors not infiltrated by $\mathrm{CD}^{+} \mathrm{T}$ cells (25).

The localization of $\mathrm{T}_{\mathrm{RM}}$ inside the tumor may be a parameter to take into account to assess their impact on the control of the tumor. Indeed, intraepithelial CD103 but not intra-stromal CD103 correlated with better overall survival and absence of relapse in a basal-like subtype of breast cancers (30). In many of these studies, the CD103 marker was analyzed and not really $\mathrm{T}_{\mathrm{RM}}$ 
$\left(\mathrm{CD}_{103}{ }^{+} \mathrm{CD}^{+} \mathrm{T}\right.$ cells). Since CD103 is also expressed by $\mathrm{CD} 4^{+}$ T cells, innate lymphoid cells, NK cells, and dendritic cells (DCs), it could introduce a bias in the interpretation of the results.

Interestingly, the genetic variability of TCRs from resident memory $\mathrm{T}$ cells between different metastatic lesions from the same patient was greater than the variance in mutational or neoepitope load in tumor cells (37). This absence of equilibration between tissue-resident TCR within individual metastases may affect the clinical results of immunotherapy at the various sites and explain mixed clinical response.

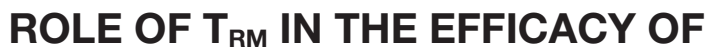 CANCER VACCINE}

Using a model of orthotopic head and neck or lung cancer, we showed that only the intranasal route of immunization elicited local $\mathrm{T}_{\mathrm{RM}}$. By means of parabiosis experiment or the use of the FTY720 inhibitor, which downregulates the S1PR1 receptor and blocks the recruitment of circulating memory $\mathrm{T}$ cells in the tissue, we demonstrated that the $\mathrm{T}_{\mathrm{RM}}$ alone could partially control the growth of the tumor $(33,38)$. It was also reported that an intravaginal boost with an HPV vaccine after a systemic (intramuscular) prime was more efficient at eliciting local cervical $\mathrm{T}_{\mathrm{RM}}$ cells, which led to a better overall mouse survival after a tumor challenge than that observed with an intramuscular boost (39).

In melanoma patients vaccinated with a mixture of Melan-A peptide combined with Montanide and $\mathrm{CpG}$, the ability to elicit anti-Melan $\mathrm{A} \mathrm{CD}^{+} \mathrm{T}$ cells expressing VLA-1, a surrogate marker of $\mathrm{T}_{\mathrm{RM}}$, was correlated with better survival (40).

Treatment of breast DCs with $\beta$-glucan-a ligand of dectin- 1 reprogrammed DC with an upregulation of ITGB8, an integrin which binds the latent domain (LAP) of TGF- $\beta$, and which after its cleavage constitutes the main mechanism of TGF- $\beta$ activation in vivo. Administration of DC treated with $\beta$-glucan curdlan or its direct intratumoral delivery induced intratumoral antitumor $\mathrm{CD}^{+}$T cells expressing CD103, which inhibit tumor progression in a humanized mouse model of breast cancer (41).

While these examples strongly suggest the role of $\mathrm{T}_{\mathrm{RM}}$ in the protection generated by cancer vaccine, it has to be kept in mind that FTY720 experiments showed that the recruitment of circulating effector memory $\mathrm{T}$ cells increased the efficacy of $\mathrm{T}_{\mathrm{RM}}$ after mucosal vaccine (33). Conversely, Dr. Sancho's group reported that, while both $\mathrm{T}_{\mathrm{RM}}$ cells and circulating memory $\mathrm{T}$ cells play a role in tumor immunosurveillance, the presence of $\mathrm{T}_{\mathrm{RM}}$ cells improves vaccine efficacy (42).

\section{ROLE OF $T_{\text {RM }}$ IN ADOPTIVE T CELL THERAPY}

Mucosal CD $103^{+} \mathrm{CD}^{+} \mathrm{T}$ cells elicited by reprogrammed DC with $\beta$-glucan curdlan can reject an established tumor and this effect is inhibited by the blockade of CD103 (41).

The establishment of $\mathrm{T}_{\mathrm{RM}}$ cell populations in various normal tissues and in cancer required the expression of Runx3 (15). In a preclinical model of melanoma, CD8 ${ }^{+}$TIL not expressing Runx-3 did not accumulate in tumor microenvironment, resulting in uncontrolled tumor growth and low survival. By contrast, when antitumor $\mathrm{CD}^{+} \mathrm{T}$ cells that overexpress Runx3 were transferred in vivo, tumor growth was inhibited, and mice survival improved (15). Thus, the adoptive $\mathrm{T}$ cell therapy of $\mathrm{T}_{\mathrm{RM}}$ seems a promising strategy.

\section{ROLE OF $T_{\text {RM IN CANCER }}$ IMMUNOTHERAPY BASED ON THE BLOCKADE OF IMMUNE CHECKPOINT MOLECULES}

$\mathrm{T}_{\mathrm{RM}}$ from healthy organs (brain, gut, lung, and skin) or localized in tumors (NSCLC, melanoma, etc.) express higher amounts of inhibitory receptors (PD-1, Tim-3, CTLA-4, NKG2A, BTLA, LAG-3, SPRY1, adenosine receptor A2AR, CD39, CD101, and 2B4) and costimulatory molecules (CD27, ICOS, SIRPG, and $\mathrm{CD} 137)$ than peripheral memory $\mathrm{CD}^{+} \mathrm{T}$ cells or $\mathrm{CD}^{+} \mathrm{CD} 103^{\text {neg }}$ TIL $(5,13,20,34,37)$.

However, depending on the tumor localization, the profile of immune checkpoint molecules detected on $\mathrm{T}_{\mathrm{RM}}$ may vary. For example, $\mathrm{T}_{\mathrm{RM}}$ derived from NSCLC and melanoma did not express membrane CTLA-4 $(19,35)$, and in ovarian cancer, $\mathrm{PD}-1^{+} \mathrm{CD} 103^{+} \mathrm{CD}^{+} \mathrm{T}$ cells exhibited a weak expression of other exhaustion-associated markers, such as CTLA-4, LAG-3, and TIM-3 (32).

TCGA analysis of cervical cancer data shows that CD103 (ITGAE) expression correlates with the usual T cell genes such as $C D 8 A$, but more interestingly also with $\mathrm{T}$ cell activation and exhaustion markers such as CTLA-4, CD137, PD-1, and PD-L1 (36).

Transcriptomic analysis of $\mathrm{T}_{\mathrm{RM}}$ also reported the expression of genes with well-recognized inhibitory functions in $\mathrm{T}$ cells, such as the dual specificity phosphatase DUSP6, which turns off MAP kinase signaling, as well as IL-10 (20). However, despite high expression of checkpoint inhibitors, several arguments show that $\mathrm{T}_{\mathrm{RM}}$ cells from infected organs or tumors are not terminally exhausted. Indeed, $\mathrm{T}_{\mathrm{RM}}$ in the hepatitis $\mathrm{B}$ virus-infected human liver co-express PD-1 and CD39 at high levels, but they readily produce IFN- $\gamma, \mathrm{TNF} \alpha$, and IL-2 after in vitro stimulation (26).

In addition, when $\mathrm{T}_{\mathrm{RM}}$ cells sorted from lung carcinomas were co-cultured with autologous tumor cells, their cytotoxic activity was enhanced in the presence of anti-PD-1 mAb (19).

In a preclinical model, administration of anti-PD-1 antibody concomitantly with Tcm transfer (which converts to $\mathrm{T}_{\mathrm{RM}}$ ) in a tumor therapy setting inhibited the growth of s.c. MC38-OVA tumor and i.d. B16-OVA tumor when compared with the adoptive $\mathrm{T}$ cell therapy with Tcm cells only. Interestingly, after anti-PD-1 therapy, the number and frequency of TIL with a $\mathrm{T}_{\mathrm{RM}}$ phenotype were increased more than 10 -fold within the CD $45^{+}$cells in both tumor settings (42).

In humans, tumor-resident $\mathrm{CD} 8^{+} \mathrm{T}$ cells significantly expanded early during anti-PD-1 treatment (35). There was a significant difference in their numbers $\left(\mathrm{T}_{\mathrm{RM}}\right)$ early during treatment between those who responded to the treatment and those who did not respond (35). In line with these results, Wei et al. showed that 
T cell clones that expanded during anti-PD-1 treatment expressed high levels of CD69, PD-1, LAG-3, and CD45RO, an identical phenotype to the tumor-resident $\mathrm{CD}^{+} \mathrm{T}$ cell population (43).

\section{CUES TO ELICIT T $T_{\text {RM }}$ TO IMPROVE CANCER IMMUNOTHERAPY}

From these results, it is clear that $\mathrm{T}_{\mathrm{RM}}$ are involved in the efficacy of different cancer immunotherapy strategies. A field of future investigation will rely on the development of new strategies to induce and amplify $\mathrm{T}_{\mathrm{RM}}$ (Figure $\mathbf{1}$ ).

\section{Route of Immunization}

Compelling experiments demonstrate the crucial role of the route of vaccination to elicit tissue-resident memory $\mathrm{T}$ cells both during natural infection and after vaccine administration.

Indeed, various vaccine studies showed that intravaginal immunization or a systemic prime followed by a mucosal vaginal boost maximized the induction of genital $\mathrm{T}_{\mathrm{RM}}$ (31). Intranasal vaccination with a recombinant cytomegalovirus vector encoding the respiratory syncytial virus (RSV) matrix (M) or with BCG protein also generated robust and durable tissue-resident effectors that were undetectable after intraperitoneal or subcutaneous vaccination $(44,45)$.

\section{Local Signal to Favor the Recruitment of $\mathrm{T}_{\mathrm{RM}}$}

In mice, cancer vaccine synergizes with local radiation to favor the recruitment of intratumoral antitumor $\mathrm{CD} 8^{+} \mathrm{T}$ cells, some of them exhibiting a $\mathrm{T}_{\mathrm{RM}}$ phenotype $(36,46)$.

Local injection of Toll-like receptor agonists or of selected chemokines via the modification of the expression of selectins, integrins, and chemokines could also enhance the recruitment of $\mathrm{CD}^{+} \mathrm{T}$ cells in the tissue and at local tumor site. This concept has been assessed in vivo by the "prime and pull" strategy, which comprises two steps: conventional systemic immunization to induce T-cell responses in the blood (prime), followed by secondary recruitment of effector $\mathrm{T}$ cells by means of local chemokine injection into the mucosal genital tract (pull). This prime-pull strategy succeeded in establishing a long-term residency and thus favored protective immunity. In mice, this prime and pull strategy was shown to decrease the diffusion of infectious herpes simplex virus 2 (HSV-2) into the sensory neurons and to be efficient to control clinical disease (18). In line with these results, after systemic administration of a vaccine, an intravesical administration of Ty21, a live bacterium used against typhoid fever or an intravaginal administration of $\mathrm{CpG}$ resulted in the accumulation of local specific $\mathrm{CD} 8^{+} \mathrm{T}$ cells and led to tumor regression $(47,48)$.

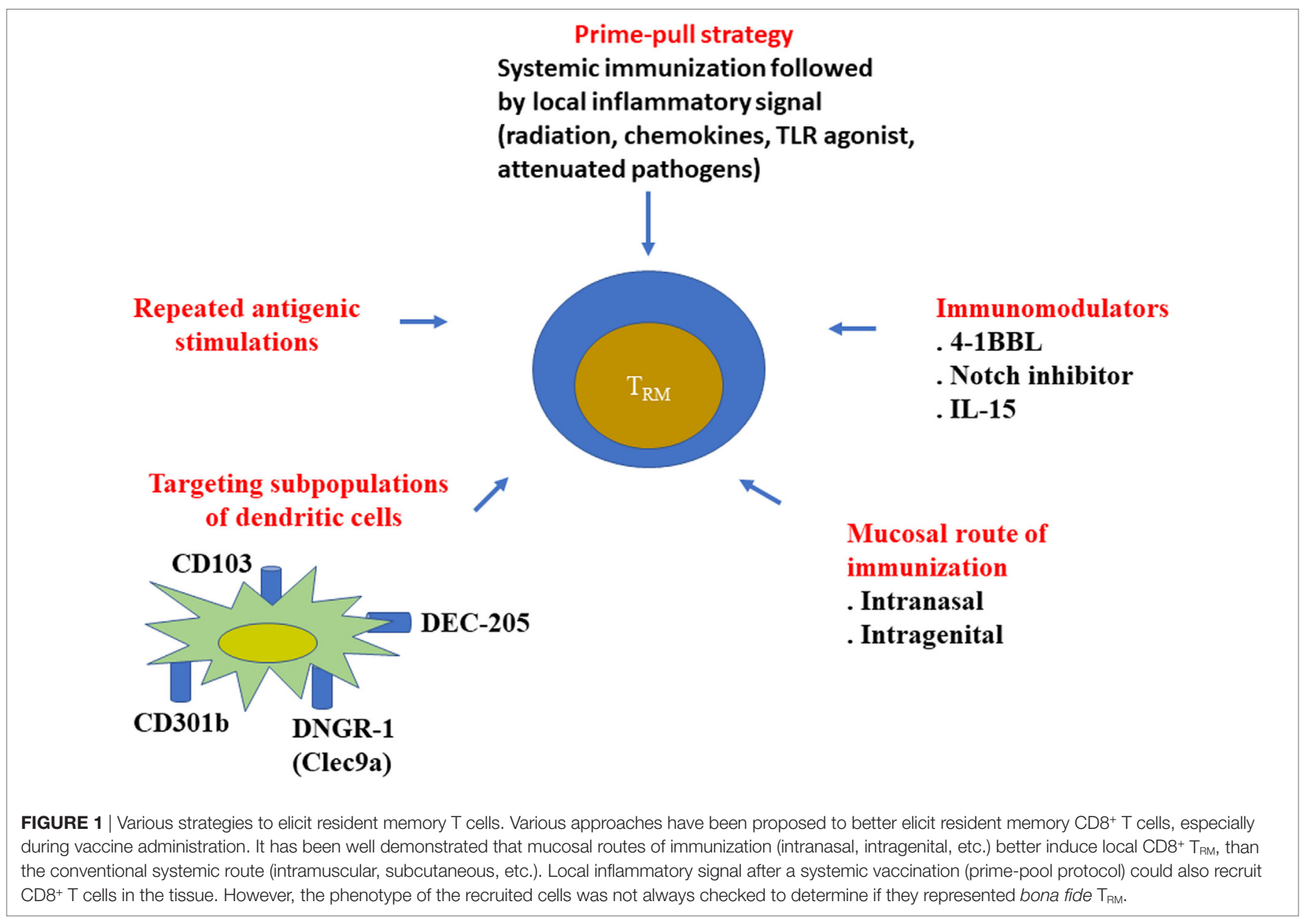


This prime-pull strategy is thus an attractive strategy, but the phenotype of these intratissular-recruited $\mathrm{CD} 8^{+} \mathrm{T}$ cells has not been fully established. In addition, it has not been reported whether these cells represent bona fide $\mathrm{T}_{\mathrm{RM}}$.

\section{Targeting DCs to Elicit $\mathbf{T}_{\mathrm{RM}}$}

Optimal generation of $\mathrm{T}_{\mathrm{RM}}$ cells requires $\mathrm{CD} 103^{+} \mathrm{DCs}$ in nonlymphoid tissues, which are dependent on the transcription factor BATF3 for their development, as well as mouse CD8 $\alpha^{+}$DCs in lymphoid organs (49). CLEC9A (DNGR-1) and DEC-205 are highly expressed by $\mathrm{CD}_{103}{ }^{+} \mathrm{DC}$ and $\mathrm{CD} 8 \alpha \mathrm{DC}$. Intranasal delivery of targeting antibodies (DEC-205 or CLEC9A) proved highly protective against lethal influenza challenge (50). This protection is based on both the initiation of T-cell priming in the lung and the enhancement of local presentation and differentiation of $\mathrm{T}_{\mathrm{RM}}$ cell (50).

$\mathrm{CD} 301 \mathrm{~b}^{+} \mathrm{DCs}$ also promote $\mathrm{CD}^{+} \mathrm{T}$ cells with a $\mathrm{T}_{\mathrm{RM}}$ phenotype which control genital HSV-2 infection (51).

In humans, lung-resident CD1c ${ }^{+}$DCs drove CD103 expression on effector $\mathrm{CD}^{+} \mathrm{T}$ cells by displaying membrane-bound TGF- $\beta 1$ (52).

\section{Immunomodulators}

Intranasal delivery of 4-1BBL in combination with an adenovirus encoding an influenza nucleoprotein to naïve mice elicits systemic effector memory CD8 ${ }^{+} \mathrm{T}$-cell expressing IL-7R $\alpha$, as well as an intraparenchymal lung $\mathrm{CD} 69^{+} \mathrm{CD} 8 \mathrm{~T}_{\mathrm{RM}}$ population, which comprised both $\mathrm{CD}_{103^{+}}$and $\mathrm{CD} 103^{\text {neg }}$ cells. Moreover, physiologically, during primary influenza infection, $\mathrm{T}$ cells deficient for $4-1 \mathrm{BB}$ do not differentiate into lung-resident $\mathrm{T}_{\mathrm{RM}}$ population (53).

Formalin inactivated RSV plus CpG plus L685,458, an inhibitor of Notch signaling, promoted protective $\mathrm{CD} 8^{+}$lung tissueresident memory $\mathrm{T}$ cells (54).

IL-15 complexes delivered locally to mucosal tissues without reinfection are an effective strategy to enhance establishment of tissue-resident memory CD8 T cells within mucosal tissues (55).

Our group showed that cancer vaccine administered by the intranasal route in combination with an anti-TGF $\beta$ decreased the

\section{REFERENCES}

1. Gebhardt T, Wakim LM, Eidsmo L, Reading PC, Heath WR, Carbone FR. Memory T cells in nonlymphoid tissue that provide enhanced local immunity during infection with herpes simplex virus. Nat Immunol (2009) 10(5):524-30. doi:10.1038/ni.1718

2. Masopust D, Choo D, Vezys V, Wherry EJ, Duraiswamy J, Akondy R, et al. Dynamic T cell migration program provides resident memory within intestinal epithelium. J Exp Med (2010) 207(3):553-64. doi:10.1084/jem.20090858

3. Clark RA. Resident memory T cells in human health and disease. Sci Transl Med (2015) 7(269):269rv1. doi:10.1126/scitranslmed.3010641

4. Sathaliyawala T, Kubota M, Yudanin N, Turner D, Camp P, Thome JJ, et al. Distribution and compartmentalization of human circulating and tissueresident memory T cell subsets. Immunity (2013) 38(1):187-97. doi:10.1016/j. immuni.2012.09.020

5. Mackay LK, Rahimpour A, Ma JZ, Collins N, Stock AT, Hafon ML, et al. The developmental pathway for CD103(+)CD8+ tissue-resident memory T cells of skin. Nat Immunol (2013) 14(12):1294-301. doi:10.1038/ni.2744 number of $\mathrm{T}_{\mathrm{RM}}$ without having any impact on $\mathrm{T}$ effector cells, and partially inhibited the protective effect of the vaccination (33).

\section{Repeated Antigenic Stimulation}

We and other showed that the density of $\mathrm{T}_{\mathrm{RM}}$ in tissues and tumors progressively increased after each immunization (33). Prime boost immunization with recombinant adenovirus expressing HPV16 E7 protein via a homologous (intravaginal) or heterologous (intramuscular followed by intravaginal) route of immunization elicited more $\mathrm{T}_{\mathrm{RM}}$ in the cervicovaginal mucosa than did a single priming by the intravaginal route (56). Multiple infections also result in more widespread or global $\mathrm{T}_{\mathrm{RM}}$ dissemination (21).

\section{CONCLUSION}

In the recent past, $\mathrm{T}_{\mathrm{RM}}$ have been emerging as having an important role in cancer immunotherapy based on cancer vaccine, adoptive cell therapy, and the blocking of the interaction of immune checkpoint molecules with their ligands. In the next few years, it will be necessary to better distinguish subpopulations of $\mathrm{T}_{\mathrm{RM}}$ in different tissues with different phenotypes and functions. The vast majority of studies focus(ed) on $\mathrm{CD}^{+} \mathrm{T}_{\mathrm{RM}}$. Further analysis of $\mathrm{CD}^{+} \mathrm{T}_{\mathrm{RM}}$ with phenotype and function that may be different from $\mathrm{CD} 8^{+}$ $\mathrm{T}_{\mathrm{RM}}$ should be performed. Optimization of immunotherapy strategies to induce these $\mathrm{T}_{\mathrm{RM}}$ is already the subject of ongoing work. Their role as a biomarker of responses to immunotherapy is also being evaluated based on preliminary encouraging results.

\section{AUTHOR CONTRIBUTIONS}

All authors listed have made substantial and direct intellectual contributions to the work and approved it for publication.

\section{FUNDING}

Institut national du Cancer (INCa) PL-Bio 2016 (ET), Labex Immuno-oncology, CARPEM (SIRIC), ANR Selectimmuno, Canceropole (ET). CG is a recipient of a Carpem fellowship and AS a recipient of Fondation Foncer.
6. Gaide O, Emerson RO, Jiang X, Gulati N, Nizza S, Desmarais C, et al. Common clonal origin of central and resident memory $\mathrm{T}$ cells following skin immunization. Nat Med (2015) 21(6):647-53. doi:10.1038/nm.3860

7. Casey KA, Fraser KA, Schenkel JM, Moran A, Abt MC, Beura LK, et al. Antigen-independent differentiation and maintenance of effector-like resident memory T cells in tissues. J Immunol (2012) 188(10):4866-75. doi:10.4049/ jimmunol.1200402

8. McMaster SR, Wilson JJ, Wang H, Kohlmeier JE. Airway-resident memory CD8 $\mathrm{T}$ cells provide antigen-specific protection against respiratory virus challenge through rapid IFN-gamma production. J Immunol (2015) 195(1):203-9. doi:10.4049/jimmunol.1402975

9. Ely KH, Cookenham T, Roberts AD, Woodland DL. Memory T cell populations in the lung airways are maintained by continual recruitment. J Immunol (2006) 176(1):537-43. doi:10.4049/jimmunol.176.1.537

10. Skon CN, Lee JY, Anderson KG, Masopust D, Hogquist KA, Jameson SC. Transcriptional downregulation of S1pr1 is required for the establishment of resident memory CD8+ T cells. Nat Immunol (2013) 14(12):1285-93 doi:10.1038/ni.2745 
11. Pan Y, Tian T, Park CO, Lofftus SY, Mei S, Liu X, et al. Survival of tissueresident memory $\mathrm{T}$ cells requires exogenous lipid uptake and metabolism. Nature (2017) 543(7644):252-6. doi:10.1038/nature21379

12. Mackay LK, Wynne-Jones E, Freestone D, Pellicci DG, Mielke LA, Newman DM, et al. T-box transcription factors combine with the cytokines TGF-beta and IL-15 to control tissue-resident memory T cell fate. Immunity (2015) 43(6):1101-11. doi:10.1016/j.immuni.2015.11.008

13. Hombrink P, Helbig C, Backer RA, Piet B, Oja AE, Stark R, et al. Programs for the persistence, vigilance and control of human CD8+ lung-resident memory T cells. Nat Immunol (2016) 17(12):1467-78. doi:10.1038/ni.3589

14. Zaid A, Mackay LK, Rahimpour A, Braun A, Veldhoen M, Carbone FR, et al. Persistence of skin-resident memory T cells within an epidermal niche. Proc Natl Acad Sci U S A (2014) 111(14):5307-12. doi:10.1073/pnas.1322292111

15. Milner JJ, Toma C, Yu B, Zhang K, Omilusik K, Phan AT, et al. Runx3 programs CD8(+) T cell residency in non-lymphoid tissues and tumours. Nature (2017) 552(7684):253-7. doi:10.1038/nature24993

16. Takamura S, Yagi H, Hakata Y, Motozono C, McMaster SR, Masumoto T, et al. Specific niches for lung-resident memory CD8+ T cells at the site of tissue regeneration enable CD69-independent maintenance. J Exp Med (2016) 213(13):3057-73. doi:10.1084/jem.20160938

17. Wakim LM, Woodward-Davis A, Bevan MJ. Memory T cells persisting within the brain after local infection show functional adaptations to their tissue of residence. Proc Natl Acad Sci U S A (2010) 107(42):17872-9. doi:10.1073/ pnas. 1010201107

18. Shin $\mathrm{H}$, Iwasaki A. A vaccine strategy that protects against genital herpes by establishing local memory T cells. Nature (2012) 491(7424):463-7. doi:10.1038/ nature11522

19. Djenidi F, Adam J, Goubar A, Durgeau A, Meurice G, de Montpreville V, et al. CD8+CD103+ tumor-infiltrating lymphocytes are tumor-specific tissueresident memory $\mathrm{T}$ cells and a prognostic factor for survival in lung cancer patients. J Immunol (2015) 194(7):3475-86. doi:10.4049/jimmunol.1402711

20. Kumar BV, Ma W, Miron M, Granot T, Guyer RS, Carpenter DJ, et al. Human tissue-resident memory $\mathrm{T}$ cells are defined by core transcriptional and functional signatures in lymphoid and mucosal sites. Cell Rep (2017) 20(12):2921-34. doi:10.1016/j.celrep.2017.08.078

21. Jiang X, Clark RA, Liu L, Wagers AJ, Fuhlbrigge RC, Kupper TS. Skin infection generates non-migratory memory CD8+ T(RM) cells providing global skin immunity. Nature (2012) 483(7388):227-31. doi:10.1038/nature10851

22. Ariotti S, Hogenbirk MA, Dijkgraaf FE, Visser LL, Hoekstra ME, Song JY, et al. $\mathrm{T}$ cell memory. Skin-resident memory CD8(+) T cells trigger a state of tissue-wide pathogen alert. Science (2014) 346(6205):101-5. doi:10.1126/ science. 1254803

23. Schenkel JM, Fraser KA, Beura LK, Pauken KE, Vezys V, Masopust D. $\mathrm{T}$ cell memory. Resident memory CD8 T cells trigger protective innate and adaptive immune responses. Science (2014) 346(6205):98-101. doi:10.1126/ science. 1254536

24. Beura LK, Mitchell JS, Thompson EA, Schenkel JM, Mohammed J, Wijeyesinghe $\mathrm{S}$, et al. Intravital mucosal imaging of $\mathrm{CD} 8(+)$ resident memory $\mathrm{T}$ cells shows tissue-autonomous recall responses that amplify secondary memory. Nat Immunol (2018) 19(2):173-82. doi:10.1038/ s41590-017-0029-3

25. Webb JR, Milne K, Watson P, Deleeuw RJ, Nelson BH. Tumor-infiltrating lymphocytes expressing the tissue resident memory marker CD103 are associated with increased survival in high-grade serous ovarian cancer. Clin Cancer Res (2014) 20(2):434-44. doi:10.1158/1078-0432.CCR-13-1877

26. Pallett LJ, Davies J, Colbeck EJ, Robertson F, Hansi N, Easom NJW, et al. IL-2(high) tissue-resident T cells in the human liver: sentinels for hepatotropic infection. J Exp Med (2017) 214(6):1567-80. doi:10.1084/jem.20162115

27. Cheuk S, Schlums H, Gallais Serezal I, Martini E, Chiang SC, Marquardt N, et al. CD49a expression defines tissue-resident CD8(+) T cells poised for cytotoxic function in human skin. Immunity (2017) 46(2):287-300. doi:10.1016/j. immuni.2017.01.009

28. Gros A, Robbins PF, Yao X, Li YF, Turcotte S, Tran E, et al. PD-1 identifies the patient-specific $\mathrm{CD} 8(+)$ tumor-reactive repertoire infiltrating human tumors. J Clin Invest (2014) 124(5):2246-59. doi:10.1172/JCI73639

29. Gros A, Parkhurst MR, Tran E, Pasetto A, Robbins PF, Ilyas S, et al. Prospective identification of neoantigen-specific lymphocytes in the peripheral blood of melanoma patients. Nat Med (2016) 22(4):433-8. doi:10.1038/nm.4051
30. Wang ZQ, Milne K, Derocher H, Webb JR, Nelson BH, Watson PH. CD103 and intratumoral immune response in breast cancer. Clin Cancer Res (2016) 22(24):6290-7. doi:10.1158/1078-0432.CCR-16-0732

31. Nizard M, Roussel H, Tartour E. Resident memory $\mathrm{T}$ cells as surrogate markers of the efficacy of cancer vaccines. Clin Cancer Res (2016) 22(3):530-2. doi:10.1158/1078-0432.CCR-15-2364

32. Webb JR, Milne K, Nelson BH. PD-1 and CD103 are widely coexpressed on prognostically favorable intraepithelial CD8 T cells in human ovarian cancer. Cancer Immunol Res (2015) 3(8):926-35. doi:10.1158/2326-6066.CIR-14-0239

33. Nizard M, Roussel H, Diniz MO, Karaki S, Tran T, Voron T, et al. Induction of resident memory $\mathrm{T}$ cells enhances the efficacy of cancer vaccine. Nat Commun (2017) 8:15221. doi:10.1038/ncomms15221

34. Ganesan AP, Clarke J, Wood O, Garrido-Martin EM, Chee SJ, Mellows T, et al. Tissue-resident memory features are linked to the magnitude of cytotoxic $\mathrm{T}$ cell responses in human lung cancer. Nat Immunol (2017) 18(8):940-50. doi:10.1038/ni.3775

35. Edwards J, Wilmott JS, Madore J, Gide TN, Quek C, Tasker A, et al. CD103(+) tumor-resident CD8(+) $\mathrm{T}$ cells are associated with improved survival in immunotherapy-naive melanoma patients and expand significantly during anti-PD-1 treatment. Clin Cancer Res (2018) 24(13):3036-45. doi:10.1158/1078-0432.CCR-17-2257

36. Komdeur FL, Prins TM, van de Wall S, Plat A, Wisman GBA, Hollema H, et al. $\mathrm{CD} 103+$ tumor-infiltrating lymphocytes are tumor-reactive intraepithelial $\mathrm{CD} 8+\mathrm{T}$ cells associated with prognostic benefit and therapy response in cervical cancer. Oncoimmunology (2017) 6(9):e1338230. doi:10.1080/2162402X. 2017.1338230

37. Boddupalli CS, Bar N, Kadaveru K, Krauthammer M, Pornputtapong N, Mai Z, et al. Interlesional diversity of $\mathrm{T}$ cell receptors in melanoma with immune checkpoints enriched in tissue-resident memory T cells. JCI Insight (2016) 1(21):e88955. doi:10.1172/jci.insight. 88955

38. Sandoval F, Terme M, Nizard M, Badoual C, Bureau MF, Freyburger L, et al. Mucosal imprinting of vaccine-induced CD8+ T cells is crucial to inhibit the growth of mucosal tumors. Sci Transl Med (2013) 5(172):172ra20. doi:10.1126/ scitranslmed.3004888

39. Sun YY, Peng S, Han L, Qiu J, Song L, Tsai Y, et al. Local HPV recombinant vaccinia boost following priming with an HPV DNA vaccine enhances local HPV-specific CD8+ T-cell-mediated tumor control in the genital tract. Clin Cancer Res (2016) 22(3):657-69. doi:10.1158/1078-0432.CCR-15-0234

40. Murray T, Fuertes Marraco SA, Baumgaertner P, Bordry N, Cagnon L, Donda A, et al. Very late antigen-1 marks functional tumor-resident CD8 $\mathrm{T}$ cells and correlates with survival of melanoma patients. Front Immunol (2016) 7:573. doi:10.3389/fimmu.2016.00573

41. Wu TC, Xu K, Banchereau R, Marches F, Yu CI, Martinek J, et al. Reprogramming tumor-infiltrating dendritic cells for CD103+ CD8+ mucosal T-cell differentiation and breast cancer rejection. Cancer Immunol Res (2014) 2(5):487-500. doi:10.1158/2326-6066.CIR-13-0217

42. Enamorado M, Iborra S, Priego E, Cueto FJ, Quintana JA, Martinez-Cano S, et al. Enhanced anti-tumour immunity requires the interplay between resident and circulating memory CD8(+) T cells. Nat Commun (2017) 8:16073. doi:10.1038/ncomms16073

43. Wei SC, Levine JH, Cogdill AP, Zhao Y, Anang NAS, Andrews MC, et al. Distinct cellular mechanisms underlie anti-CTLA-4 and anti-PD-1 checkpoint blockade. Cell (2017) 170(6):1120-33.e17. doi:10.1016/j.cell.2017.07.024

44. Perdomo C, Zedler U, Kuhl AA, Lozza L, Saikali P, Sander LE, et al. Mucosal BCG vaccination induces protective lung-resident memory $\mathrm{T}$ cell populations against tuberculosis. $m$ Bio (2016) 7(6):e01686-16. doi:10.1128/mBio.01686-16

45. Morabito KM, Ruckwardt TR, Redwood AJ, Moin SM, Price DA, Graham BS. Intranasal administration of RSV antigen-expressing MCMV elicits robust tissue-resident effector and effector memory CD8+ T cells in the lung. Mucosal Immunol (2017) 10(2):545-54. doi:10.1038/mi.2016.48

46. Mondini M, Nizard M, Tran T, Mauge L, Loi M, Clemenson C, et al. Synergy of radiotherapy and a cancer vaccine for the treatment of HPV-associated head and neck cancer. Mol Cancer Ther (2015) 14(6):1336-45. doi:10.1158/15357163.MCT-14-1015

47. Domingos-Pereira S, Decrausaz L, Derre L, Bobst M, Romero P, Schiller JT, et al. Intravaginal TLR agonists increase local vaccine-specific CD8 T cells and human papillomavirus-associated genital-tumor regression in mice. Mucosal Immunol (2013) 6(2):393-404. doi:10.1038/mi.2012.83 
48. Domingos-Pereira S, Hojeij R, Reggi E, Derre L, Chevalier MF, Romero P, et al. Local Salmonella immunostimulation recruits vaccine-specific CD8 $\mathrm{T}$ cells and increases regression of bladder tumor. Oncoimmunology (2015) 4(7):e1016697. doi:10.1080/2162402X.2015.1016697

49. Iborra S, Martinez-Lopez M, Khouili SC, Enamorado M, Cueto FJ, CondeGarrosa R, et al. Optimal generation of tissue-resident but not circulating memory $\mathrm{T}$ cells during viral infection requires crosspriming by DNGR-1(+) dendritic cells. Immunity (2016) 45(4):847-60. doi:10.1016/j.immuni.2016. 08.019

50. Wakim LM, Smith J, Caminschi I, Lahoud MH, Villadangos JA. Antibodytargeted vaccination to lung dendritic cells generates tissue-resident memory CD8 $\mathrm{T}$ cells that are highly protective against influenza virus infection. Mucosal Immunol (2015) 8(5):1060-71. doi:10.1038/mi.2014.133

51. Shin H, Kumamoto Y, Gopinath S, Iwasaki A. CD301b+ dendritic cells stimulate tissue-resident memory CD8+ T cells to protect against genital HSV-2. Nat Commun (2016) 7:13346. doi:10.1038/ncomms 13346

52. Yu CI, Becker C, Wang Y, Marches F, Helft J, Leboeuf M, et al. Human $\mathrm{CD} 1 \mathrm{c}(+)$ dendritic cells drive the differentiation of CD103(+) CD8(+) mucosal effector T cells via the cytokine TGF-beta. Immunity (2013) 38(4):818-30. doi:10.1016/j.immuni.2013.03.004

53. Zhou AC, Wagar LE, Wortzman ME, Watts TH. Intrinsic 4-1BB signals are indispensable for the establishment of an influenza-specific tissue-resident memory CD8 T-cell population in the lung. Mucosal Immunol (2017) 10(5):1294-309. doi:10.1038/mi.2016.124
54. Zhang L, Li H, Hai Y, Yin W, Li W, Zheng B, et al. CpG in combination with an inhibitor of notch signaling suppresses formalin-inactivated respiratory syncytial virus-enhanced airway hyperresponsiveness and inflammation by inhibiting Th17 memory responses and promoting tissue-resident memory cells in lungs. J Virol (2017) 91(10):e02111-16. doi:10.1128/JVI.02111-16

55. Sowell RT, Goldufsky JW, Rogozinska M, Quiles Z, Cao Y, Castillo EF, et al. IL15 complexes induce migration of resting memory CD8 T cells into mucosal tissues. J Immunol (2017) 199(7):2536-46. doi:10.4049/jimmunol.1501638

56. Cuburu N, Khan S, Thompson CD, Kim R, Vellinga J, Zahn R, et al. Adenovirus vector-based prime-boost vaccination via heterologous routes induces cervicovaginal CD8(+) T cell responses against HPV16 oncoproteins. Int J Cancer (2018) 142(7):1467-79. doi:10.1002/ijc.31166

Conflict of Interest Statement: The authors declare that the research was conducted in the absence of any commercial or financial relationships that could be construed as a potential conflict of interest.

Copyright (C) 2018 Blanc, Hans, Tran, Granier, Saldman, Anson, Oudard and Tartour. This is an open-access article distributed under the terms of the Creative Commons Attribution License (CC BY). The use, distribution or reproduction in other forums is permitted, provided the original author(s) and the copyright owner(s) are credited and that the original publication in this journal is cited, in accordance with accepted academic practice. No use, distribution or reproduction is permitted which does not comply with these terms. 